UDC 579.261

DOI: 10.20535/1810-0546.2017.3.95070

L.M. Lazarenko ${ }^{1 *}$, L.P. Babenko ${ }^{1}$, V.V. Mokrozub ${ }^{1}$, M.A. Voronkevych ${ }^{1}$, D.V. Loseva ${ }^{1}$, L.M. Sichel ${ }^{1,2}$, M.Ya. Spivak ${ }^{1,3}$

${ }^{1}$ D.K. Zabolotny Institute of Microbiology and Virology of NASU, Kyiv, Ukraine

${ }^{2}$ Pure Research Products, LLC, Colorado, USA

${ }^{3}$ LCL "DIAPROF", Kyiv, Ukraine

\title{
THE EFFECT OF LACTIC ACID BACTERIA AND BIFIDOBACTERIA ON THE NUMBER OF NATURAL KILLER CELLS IN NORMAL CONDITIONS AND IN CASES OF INTRAVAGINAL STAPHYLOCOCCOSIS IN MICE
}

Background. Development of new immunobiotics based on commensal nonpathogenic probiotic bacteria such as lactic acid bacteria and bifidobacteria with antibacterial and immunomodulatory effects is an important area of modern biotechnology.

Objective. The aim of this study was to determine the effect of Lactobacillus acidophilus IMV B-7279, L. casei IMV B-7280, L. delbrueckii subsp. bulgaricus IMV B-7281, Bifidobacterium animalis VKL and B. animalis VKB (individually) or their different compositions on the number of natural killer cells (NKC) in the spleen of BALB/c mice at normal conditions and in the case of the experimental intravaginal staphylococcosis.

Methods. The number of NKC in the spleen was studied using monoclonal phycoerythrin-conjugated antibodies against NKC antigens (MACS, Miltenyi Biotec, Germany). Calculations of NKC as well as analysis of the results were performed using flow cytometry method on a FACStar Plus cytofluorometer.

Results. It is shown that the number of NKC in the spleen of intact mice did not change under the influence of $L . a c i-$ dophilus IMV B-7279, L. casei IMV B-7280, B. animalis VKL or B. animalis VKB (individually). But, using L. acidophilus IMV B-7279, L. casei IMV B-7280, L. delbrueckii subsp. bulgaricus IMV B-7281, B. animalis VKL and B. animalis VKB (individually) or their different compositions for colonization of the vagina in the case of intravaginal staphylococcosis associated with increasing of the number of $\mathrm{NKC}$ in spleen in different periods of observation. The number of NKC in the spleen of staphylococcus-infected mice completely normalized after treatment with some probiotic compositions. The probiotic bacteria (individually) only partially normalized the number of NKC in the spleen of staphylococcus-infected mice.

Conclusions. Thus, L. acidophilus IMV B-7279, L. casei IMV B-7280, L. delbrueckii subsp. bulgaricus IMV B-7281 or $B$. animalis VKL (individually) or their various compositions are promising to create highly effective immunobiotics, that are able to increase the innate immunity in cases of infections.

Keywords: lactic acid bacteria; bifidobacteria; natural killer cells; spleen; intravaginal staphylococcosis; mice.

\section{Introduction}

Infectious diseases caused by pathogenic or opportunistic bacteria are a vast group of human diseases that are frequently associated with immunosuppression. Recently obtained evidence that in addition to neutrophils and macrophages, natural killer cells (NKC) play an important role in host defense against extracellular bacterial infections [1-3]. $\mathrm{Nu}$ merous experimental and clinical studies of antibacterial effects of activated NKC have demonstrated that they directly kill bacteria using soluble factors and have an indirect effect through interaction with other immune cells such as dendritic cells (DC), macrophages and neutrophils, through the production of cytokines (interleukin (IL)-12, IL-15, IL-18 and interferon (IFN)) [1, 4]. At several diseases, such as viral infections [5], atherosclerosis [6], chronic fa- tigue, immune dysfunction syndrome [7], cancer [8] the decrease of NKC cytotoxicity or a reduction in their number were observed that also confirms the importance of regular function of these cells in host defense.

Staphylococcus aureus that remains a common cause of nosocomial bacterial infections and asymptomatically colonize the nasal tract, rectum, mouth, genitals and skin, is often resistant to antibiotics and can cause various diseases, including pneumonia, sepsis, septic arthritis, etc. [9-11]. The cellular and molecular mechanisms of anti-staphylococcal host defense are closely associated with innate immune response especially with activity of neutrophils, macrophages and NKC [4, 11-13]. Experimental studies have shown that NKC involve in host defense against bacterial lung infection in mice [11] or in rats [13] as well as from arthritis in mice [12], which

\footnotetext{
${ }^{*}$ corresponding author: LazarenkoLM@yandex.ru
} 
was induced by $S$. aureus. Thus, the enhancement of innate immunity, in the first place activation of the neutrophils, macrophages, and NKC is a promising direction of development of new therapeutic approaches for the treatment of patients with staphylococcal infection, especially in the case of infection caused by antibiotic-resistant strains.

The use of probiotics based on commensal nonpathogenic probiotic bacteria such as lactic acid bacteria $(\mathrm{LAB})$ and bifidobacteria with antibacterial and immunomodulatory effects probably is an important part of treatment of patients with infectious diseases, including those induced by extracellular bacteria such as Staphylococcus spp etc. [14, 15]. It is known that immunomodulatory effects of probiotics are strainspecific and associated with activation of DC, macrophages, epithelial cells, $\mathrm{T}$ regulatory cells, effector lymphocytes, B-lymphocytes and NKC [15]. There is the evidence that commensal bacteria, including $\mathrm{LAB}$, affect the regulation of NKC activity and their ability to product IFN- $\gamma$ that may depends on the LAB-induced dendritic cells [16, 17], this helps them to develop a full range of special functions in the periphery and secondary lymphoid organs. On the one hand, NKC, activated by DC, kill infected or transformed cells in the periphery, and on the other hand, play a key role in Th1 polarization response upon interaction with DC [17]. Bifidobacteria also activated NKC in normal conditions and in case of pathologies [18, 19].

As we have shown in animal models [20, 21] the probiotic strains Lactobacillus acidophilus IMV B-7279, L. casei IMV B-7280, L. delbrueckii subsp. bulgaricus IMV B-7281, Bifidobacterium animalis VKL and B. animalis VKB from our collection of the probiotic bacteria have a high level of immunomodulatory properties in normal conditions and in cases of infectious and inflammatory diseases. These probiotic bacteria and their various compositions with different efficacy inhibited the persistence of $S$. $a u$ reus strain 8325-4 in the vagina of staphylococcusinfected BALB/c mice. In the case of the experimental intravaginal staphylococcosis L. casei IMV B-7280, as well as most compositions on the basis of these strains of LAB and bifidobacteria caused a normalization of cellular immunity indicators [21].

\section{Problem statement}

This study aimed to investigate if the L. acidophilus IMV B-7279, L. casei IMV B-7280, L. delbrueckii subsp. bulgaricus IMV B-7281, B. animalis VKL and B. animalis VKB (individually) or their different compositions can alter the number of NKC in the spleen of mice at normal conditions and in the case of the experimental intravaginal staphylococcosis.

\section{Materials and methods}

Experimental studies were performed on sixweek-old female BALB/c mice, synchronized in their estral cycle. All studies were performed taking into account the rules of the "European Convention for the protection of vertebrate animals used for experimental and other scientific purposes" (Strasbourg, 1986) and in accordance with "General ethical principles of experiments on animals". Mice were kept in standard vivarium conditions at a temperature of $22 \pm 1{ }^{\circ} \mathrm{C}$, they were provided with the full mixed feed and had free access to automatic water bowls.

The bacterial strains used in the study were: L. acidophilus IMV B-7279, L. casei IMV B-7280, L. delbrueckii subsp. bulgaricus IMV B-7281 (deposited in the Depositary of microorganisms of the D.K. Zabolotny Institute of Microbiology and Virology, NAS of Ukraine), B. animalis VKL and B. animalis VKB isolated from content of gut of healthy people in the course of laboratory study of fermented biological materials. The lyophilized in Cuddon Freeze Dryer FD1500 (New Zealand) probiotic bacteria were used in our study. The viability of the LAB and bifidobacteria strains was tested before each experiment by monitoring their growth on the ManRogosa-Sharpe (MRS) agar medium or Bifidum-agar medium (respectively) at $37^{\circ} \mathrm{C}$ for $24-48 \mathrm{~h}$.

$S$. aureus strain 8325-4 (kindly provided to us by Professor V.S. Zuyeva, N.F. Gamaleya Institute of Epidemiology and Microbiology, Russian Federation) that has a plasmid of resistance to gentamicin was chosen for modelling the intravaginal staphylococcosis in mice. $S$. aureus strain 8325-4 was grown on selective agar medium for staphylococci (BAIRDPARKER-Agar, Merck, Germany), which contained gentamicin at a concentration of $15 \mathrm{mg} / \mathrm{ml}$, at $37{ }^{\circ} \mathrm{C}$ for $24 \mathrm{~h}$. After that bacterial cells were washed twice with sterile phosphate-buffered saline (PBS).

Suspension of the $S$. aureus 8325-4 in PBS was administered once into vagina of BALB/c mice, in the dose of $5 \times 10^{7}$ cells per animal. The following clinical manifestations of the infection process were observed in the infected mice: significant increase in whitish mucous secretions of the vagina, elevation of body temperature, inactivity and loss of appetite. Suspension of the probiotic bacteria or their different compositions in PBS was administrated into the vagina of intact and staphylococcus-infected mice 1 day after infection at the dose of $1 \times 10^{6}$ cells per animal, once a day for 7 days. When two, three or four 
strains of probiotic bacteria were used as a composition, they were used at the concentration to achieve the total number of bacterial cells $=1 \times 10^{6}$. The probiotic compositions used in the study were: $L$. casei IMV B-7280 - B. animalis VKB, L. casei IMV B-7280 - B. animalis VKL, L. acidophilus IMV B-7279 - B. animalis VKB, L. acidophilus IMV B-7279 - B. animalis VKL, L. acidophilus IMV B-7279 - L. casei IMV B-7280, B. animalis VKL B. animalis $\mathrm{VKB}$, L. casei IMV B-7280 - B. animalis VKL - B. animalis VKB, L. casei IMV B-7280 B. animalis $\mathrm{VKL}-$ L. acidophilus IMV B-7279, L. acidophilus IMV B-7279 - B. animalis VKL - B. animalis VKB, L. casei IMV B-7280 - B. animalis VKB - L. acidophilus IMV B-7279, L. casei IMV B-7280 - B. animalis VKB - B. animalis VKL L. acidophilus IMV B-7279.

On the $1^{\text {st }}, 3^{\text {rd }}, 6^{\text {th }}$ and $9^{\text {th }}$ days after the probiotic bacteria first administration, spleens were obtained from decapitated mice of all groups who had previously received anesthesia. Leukocytes were extracted from the spleen cell suspension by fractionating cells in ficoll-verohrafin density gradient $\left(\rho=1.077 \mathrm{~g} / \mathrm{cm}^{3}\right)$ by centrifuging at $1500 \mathrm{rev} / \mathrm{min}$ for $15 \mathrm{~min}$. The cells were then washed twice in the RPMI-1640 culture medium by centrifuging at $1500 \mathrm{rev} / \mathrm{min}$ for $10 \mathrm{~min}$. Monoclonal phycoerythrinconjugated antibodies against NKC antigens (MACS, Miltenyi Biotec, Germany) were used for phenotyping of the isolated cells. Calculations of NKC, as well as analysis of the results, were performed using flow cytometry method on a FACStar Plus cytofluorometer (Becton-Dickinson, USA).

All digital data received were processed with the help of the Epi Info software (version 6.0) through analysis of variance. The null hypothesis for the control and experimental comparative groups was checked using Wilcoxon-Mann-Whitney (U) criteria. The differences between the groups were considered statistically meaningful at $P<0.05$.

\section{Results and discussion}

We have established that the effect of probiotic strains of LAB and bifidobacteria on the number of NKC in the spleen of intact and staphylococcus-infected mice was different. The number of NKC in the spleen of intact mice, whose vagina was colonized with L. casei IMV B-7280, L. acidophillus IMV B-7279, $B$. animalis VKL or B. animalis VKB (individually) remain unchanged throughout the observation period compared with intact mice that did not receive probiotic bacteria (Table 1).

In the spleen of staphylococcus-infected mice the number of NKC changed compared with intact mice, depending on the periods of observation. As shown in Table 2, statistically significant decrease in the number of NKC in the spleen of staphylococcusinfected mice was on the $1^{\text {st }}$ and $6^{\text {th }}$ days. The downward trend in the number of NKC in the spleen of staphylococcus-infected mice we observed on the $3^{\text {rd }}$ day. But, the number of NKC in the spleen of these mice was normalized on the $9^{\text {th }}$ day.

The data presented here demonstrate a time-dependent immunomodulatory effect of probiotic bacteria that we used for the purposes of vagina colonization in the case of intravaginal staphylococcosis in mice. So, treatment of staphylococcus-infected mice with L. acidophilus IMV B-7279, L. casei IMV B-7280, L. delbrueckii subsp. bulgaricus IMV B-7281 or B. animalis VKL (individually) resulted in increasing the number of NKC in the spleen in different periods of observation compared with staphylococcus-infected mice that did not receive probiotic bacteria (control group) (see Table 2). We observed a slight decrease in the number of NKC in the spleen of staphylococcus-infected mice that received $\mathrm{L}$. acidophilus IMV B-7279, L. delbrueckii subsp. bulgaricus IMV B-7281 (on the $6^{\text {th }}$ day) or L. casei IMV B-7280 (on the $3^{\text {rd }}$ day) compared with intact mice. But these changes were incomprehensible. The number of NKC in the spleens of staphylococcus-infected mice treated with $B$. animalis VKB on the $1^{\text {st }}, 3^{\text {rd }}$ and $6^{\text {th }}$ days was the same as in the control group.

Table 1. The number of NKC in the spleen of intact mice who receiving probiotic strains of LAB or bifidobacteria (individually)

\begin{tabular}{|l|c|c|c|c|}
\hline \multirow{2}{*}{\multicolumn{1}{|c|}{ Group of mice }} & \multicolumn{4}{|c|}{ NKC $(\%) /$ day of study } \\
\cline { 2 - 5 } & $1^{\text {st }}$ day & $3^{\text {rd }}$ day & $6^{\text {th }}$ day & $9^{\text {th }}$ day \\
\hline Intact mice & $9.4 \pm 1.8$ & $10.2 \pm 1.9$ & $9.9 \pm 1.2$ & $9.8 \pm 1.3$ \\
\hline Received L. acidophillus IMV B-7279 & $10.1 \pm 1.9$ & $12.3 \pm 1.8$ & $10.5 \pm 1.8$ & $9.8 \pm 1.6$ \\
\hline Received L. casei IMV B-7280 & $9.3 \pm 1.6$ & $15.9 \pm 1.8$ & $11.2 \pm 1.6$ & $9.5 \pm 1.5$ \\
\hline Received B. animalis VKL & $9.0 \pm 1.1$ & $10.9 \pm 1.7$ & $7.5 \pm 1.7$ & $7.2 \pm 1.8$ \\
\hline Received B. animalis VKB & $8.4 \pm 1.6$ & $8.7 \pm 1.6$ & $8.1 \pm 1.4$ & $7.8 \pm 1.5$ \\
\hline
\end{tabular}


Table 2. The number of NKC in the spleens of staphylococcus-infected mice who receiving probiotic bacteria (individually)

\begin{tabular}{|l|c|c|c|c|}
\hline \multirow{2}{*}{ Group of mice } & \multicolumn{4}{c|}{ NKC $(\%) /$ day of study } \\
\cline { 2 - 5 } & $1^{\text {st }}$ day & $3^{\text {rd }}$ day & $6^{\text {th }}$ day & $9^{\text {th }}$ day \\
\hline Intact mice & $10.4 \pm 1.0$ & $10.4 \pm 1.0$ & $10.4 \pm 1.0$ & $10.4 \pm 1.0$ \\
\hline Infected mice (control group) & $7.5 \pm 1.1^{*}$ & $9.1 \pm 0.7$ & $7.2 \pm 1.0^{*}$ & $11.6 \pm 0.9$ \\
\hline Received L. acidophilus IMV B-7279 & $10.7 \pm 0.7^{\bullet}$ & $10.4 \pm 1.2$ & $6.2 \pm 0.8^{*}$ & $13.0 \pm 1.4$ \\
\hline Received L. casei IMV B-7280 & $9.7 \pm 1.0$ & $7.9 \pm 0.6^{*}$ & $12.7 \pm 0.8^{\bullet}$ & $11.0 \pm 1.2$ \\
\hline Received L. delbrueckii subsp.bulgaricus IMV B-7281 & $10.9 \pm 0.4^{\bullet}$ & $11.9 \pm 1.3$ & $7.0 \pm 0.5^{*}$ & $12.3 \pm 0.6$ \\
\hline Received B. animalis VKL & $9.8 \pm 1.3$ & $10.1 \pm 0.7$ & $12.3 \pm 0.6^{\bullet}$ & $9.6 \pm 1.1^{*}$ \\
\hline Received B. animalis VKB & $7.4 \pm 0.5^{*}$ & $6.2 \pm 0.9^{*}$ & $7.6 \pm 1.4$ & $6.5 \pm 1.1^{*}$ \\
\hline
\end{tabular}

Note. Significant differences with the indicators of intact mice are represented by $*(P<0.05)$, while differences with the indicators of staphylococcus-infected mice who did not receive probiotic strains or their composition are represented by ${ }^{\bullet}(P<0.05)$.

Table 3. The number of NKC in the spleens of staphylococcus-infected mice who receiving probiotic compositions

\begin{tabular}{|c|c|c|c|c|}
\hline \multirow{2}{*}{ Group of mice } & \multicolumn{4}{|c|}{ NKC (\%)/day of study } \\
\hline & $1^{\text {st }}$ day & $3^{\text {rd }}$ day & $6^{\text {th }}$ day & $9^{\text {th }}$ day \\
\hline Intact mice & $10.4 \pm 1.0$ & $10.4 \pm 1.0$ & $10.4 \pm 1.0$ & $10.4 \pm 1.0$ \\
\hline Infected mice (control group) & $7.5 \pm 1.1^{*}$ & $9.1 \pm 0.7$ & $7.2 \pm 1.0^{*}$ & $11.6 \pm 0.9$ \\
\hline $\begin{array}{l}\text { Received L. casei IMV B-7280 - } \\
\text { B. animalis VKB }\end{array}$ & $6.5 \pm 0.3^{*}$ & $6.3 \pm 1.2^{*}$ & $14.5 \pm 1.1^{* \bullet}$ & $8.0 \pm 2.9$ \\
\hline $\begin{array}{l}\text { Received L. casei IMV B-7280 - } \\
\text { B. animalis VKL }\end{array}$ & $13.3 \pm 1.3^{\bullet}$ & $7.5 \pm 2.5$ & $11.1 \pm 1.4^{\bullet}$ & $10.0 \pm 1.6$ \\
\hline $\begin{array}{l}\text { Received L. acidophilus IMV B-7279- } \\
\text { B. animalis VKB }\end{array}$ & $12.3 \pm 1.2^{\bullet}$ & $9.4 \pm 0.7$ & $11.3 \pm 1.7^{\bullet}$ & $9.8 \pm 0.9$ \\
\hline $\begin{array}{l}\text { Received L. acidophilus IMV B-7279- } \\
\text { B. animalis VKL }\end{array}$ & $8.6 \pm 0.5$ & $7.0 \pm 0.3$ & $6.8 \pm 0.2^{*}$ & $6.2 \pm 3.1^{*}$ \\
\hline $\begin{array}{l}\text { Received L. acidophilus IMV B-7279- } \\
\text { L. casei IMV B-7280 }\end{array}$ & $12.0 \pm 1.4^{\bullet}$ & $9.8 \pm 0.9$ & $9.8 \pm 0.8$ & $10.4 \pm 1.1$ \\
\hline Received B. animalis VKL - B. animalis VKB & $11.5 \pm 1.1^{\bullet}$ & $18.4 \pm 0.9^{* \bullet}$ & $17.4 \pm 1.0^{* \bullet}$ & $12.3 \pm 1.6$ \\
\hline $\begin{array}{l}\text { Received L. casei IMV B-7280- } \\
\text { B. animalis VKL }- \text { B. animalis VKB }\end{array}$ & $7.3 \pm 1.1$ & $15.0 \pm 0.75^{* \bullet}$ & $14.0 \pm 2.4^{*}$ & $13.2 \pm 1.1$ \\
\hline $\begin{array}{l}\text { Received L. casei IMV B-7280- } \\
\text { B. animalis VKL - L. acidophilus IMV B-7279 }\end{array}$ & $18.3 \pm 0.6^{* \bullet}$ & $11.5 \pm 1.9$ & $15.2 \pm 1.1^{* \bullet}$ & $9.0 \pm 1.3$ \\
\hline $\begin{array}{l}\text { Received L. acidophilus IMV B-7279 - } \\
\text { B. animalis VKL }- \text { B. animalis VKB }\end{array}$ & $9.8 \pm 0.6$ & $8.0 \pm 0.8$ & $11.0 \pm 0.2^{\bullet}$ & $16.1 \pm 0.8^{* \bullet}$ \\
\hline $\begin{array}{l}\text { Received L. casei IMV B-7280- } \\
\text { B. animalis VKB - L. acidophilus IMV B-7279 }\end{array}$ & $7.4 \pm 0.3$ & $16.0 \pm 0.1^{* \bullet}$ & $17.7 \pm 0.7^{*}$ & $16.1 \pm 0.5^{*}$ \\
\hline $\begin{array}{l}\text { Received } L . \text { casei IMV B-7280 - } \\
\text { B. animalis VKB - B. animalis VKL - } \\
\text { L. acidophilus IMV B-7279 }\end{array}$ & $12.0 \pm 0.2^{\bullet}$ & $9.8 \pm 0.3$ & $16.9 \pm 0.4^{* \bullet}$ & $10.4 \pm 0.2$ \\
\hline
\end{tabular}

Note. Significant differences with the indicators of intact mice is represented by $*(P<0.05)$, while differences with the indicators of the staphylococcus-infected mice who did not receive probiotic strains or their composition are represented by ${ }^{\bullet}(P<0.05)$.

On the $9^{\text {th }}$ day the number of NKC in the spleens of these mice was less than in the control mice and even in intact mice.

To answer the question of whether we will have the same time-dependent immunomodulatory effect, if we are going to colonize the vagina of staphylococcus-infected mice by several probiotic strains together, we used different probiotic compositions (Table 3). As shown by our study, the most effective probiotic compositions of two probiotic strains, which significantly increased the number of NKC in the spleen of staphylococcus-infected mice, were $L . a c i-$ dophilus IMV B-7279 - B. animalis VKB, B. animalis VKL - B. animalis VKB and $L$. casei IMV B-7280 - B. animalis VKL. We have observed an increase in the number of NKC in the spleen of staphylococcus-infected mice treated with $B$. animalis VKL $-B$. animalis VKB composition on the 
$1^{\text {st }}, 3^{\text {rd }}$ and $6^{\text {th }}$ days or L. acidophilus IMV B-7279 B. animalis VKB or L. casei IMV B-7280 - B. animalis VKL compositions on the $1^{\text {st }}$ and $6^{\text {th }}$ days compared with control group. The number of NKC in the spleens of staphylococcus-infected mice that received L. acidophilus IMV B-7279 - L. casei IMV B-7280 composition was increased only on the $1^{\text {st }}$ day. However, other probiotic compositions of two strains were not effective.

Among the compositions of the three probiotic strains most effective was L. casei IMV B-7280 B. animalis $\mathrm{VKL}-$ L. acidophilus IMV B-7279. After administration of this probiotic composition into staphylococcus-infected mice the increase in the number of NKC in the spleen was observed on the $1^{\text {st }}$ and $6^{\text {th }}$ days.

The number of NKC increased in the spleen of staphylococcus-infected mice that received $L$. $c a$ sei IMV B-7280 - B. animalis VKB - B. animalis VKL composition on the $3^{\text {rd }}$ and $6^{\text {th }}$ days. Treatment of staphylococcus-infected mice with $L$. casei IMV B-7280 - B. animalis VKB - L. acidophilus IMV B-7279 composition resulted in increasing of the NKC number in the spleen of staphylococcus-infected mice on the $3^{\text {rd }}, 6^{\text {th }}$ and $9^{\text {th }}$ days. L. acidophilus IMV B-7279 - B. animalis VKL - B. animalis VKB composition was less effective. The number of NKC in the spleens of these mice was increased only on the $6^{\text {th }}$ and $9^{\text {th }}$ days. There was a significant increase in the number of NKC in the spleen of staphylococcus-infected mice that received L. casei IMV B-7280 - B. animalis VKB - B. animalis VKL - L. acidophilus IMV B-7279 composition on the $3^{\text {rd }}$ and $6^{\text {th }}$ days (see Table 3 ).

Thus, we established that the number of NKC in the spleen of intact mice did not change under the influence of any probiotic strains that we investigated. But, using L. acidophilus IMV B-7279, L. casei IMV B-7280, L. delbrueckii subsp. bulgaricus IMV B-7281 or B. animalis VKL (individually) or their different compositions for the purposes of vagina colonization in the case of intravaginal staphylococcosis was associated with increasing in the number of NKC in the spleen compared with indicators of staphylococcus-infected mice that did not receive probiotic bacteria or even with intact mice in different periods of observation.

The previous study in our laboratory showed that after L. acidophilus IMV B-7279, L. casei IMV B-7280, B. animalis VKL or B. animalis VKB (individually) and their different compositions administration into staphylococcus-infected BALB/c mice the growth of $S$. aureus in the vagina was inhibited and the number of $\mathrm{CD}^{+}$and $\mathrm{CD}^{+}{ }^{+} \mathrm{T}$-cells in the spleen, and $\mathrm{CD}^{+} / \mathrm{CD}^{+}$index, which decreased after staphylococcus infection, were increased [21]. L. acidophilus IMV B-7279, L. casei IMV B-7280, L. delbrueckii subsp. bulgaricus IMV B-7281 induced the IL-12 and IFN- $\gamma$ production by murine macrophages in vitro [22]. Thus, the use of these probiotic bacteria and their different compositions for the purposes of vagina colonization of staphylococcus-infected mice led to activation of the innate and adoptive immunity.

It should be noted that the effect of probiotic bacteria on the NKC is one of the key mechanism for strengthening of the innate immunity, which plays an important role in host defense against infections. Therefore most researchers have directed their efforts to study the effect of probiotic bacteria on the NKC activity and/or change in their number in normal conditions and in cases of pathologies. It has been found that such probiotic strains of LAB as L. pentosus S-PT84 [23], L. brevis KB290 [24], L. paracasei [25] after oral administration into intact mice significantly increased the activity of NKC. The cytotoxic activity of NKC and production of cytokines in the spleen and blood were increased in immunosuppressed mice which were treated with L. sakei K101 and L. plantarum K55-5 [26]. The number of NKC and their cytotoxicity were significantly increased in tumor-bearing $\mathrm{C} 3 \mathrm{H} / \mathrm{HeN}$ mice after $L$. casei Shirota use for treatment [27]. Oral administration of L.plantarum A into tumor-bearing $\mathrm{BALB} / \mathrm{c}$ mice led to increase of the NKC infiltration into tumor tissue and activation of the effector functions of CD8+ T-cells [28]. L. casei ssp casei significantly increased the cytotoxicity of NKC and up-regulated the production of IFN- $\gamma$ and IL-12 in the spleen cells culture in invasive ductal carcinoma bearing BALB/c mice [29].

Our results show that in the case of bacterial infections the majority of probiotic compositions used in the present study more effectively affect the number of NKC in the spleen than probiotic bacteria individually. Thus, in the spleen of staphylococcusinfected mice the number of NKC that decreased on the $1^{\text {st }}$ and $6^{\text {th }}$ days after mice were infected with $S$. aureus $8325-4$, completely normalized after use for treatment of such probiotic compositions as $L$. $c a-$ sei IMV B-7280 - B. animalis VKL, L. acidophilus IMV B-7279 - B. animalis VKB, B. animalis VKL B. animalis $\mathrm{VKB}$, L. casei IMV B-7280 - B. animalis VKL - L. acidophilus IMV B-7279 and L. casei IMV B-7280 - B. animalis VKB $-B$. animalis VKL - L. acidophilus IMV B-7279. The probiotic bacteria individually only partially normalized the number of NKC in the spleen of staphylococcus-infected mice. Perhaps, this is due to the fact that the 
probiotic bacteria used in the compositions can enhance the growth of each other after the administration into animals that may increase their ability to colonize vagina and immunomodulatory effects.

\section{Conclusions}

So, our results indicate that L. acidophilus IMV B-7279, L. casei IMV B-7280, L. delbrueckii subsp. bulgaricus IMV B-7281, B. animalis VKB and B. animalis VKL (individually) or their different probiotic compositions are promising to create highly effective immunobiotics, that are able to increase the innate immunity in cases of bacterial infections and, possibly, other pathologies. But in the case of intravaginal staphylococcosis, probiotic bacteria individually were less effective than probiotic compositions. It should be noted that for creation of highly effective immunobiotics consisting of several probiotic bacteria it is important to determine their optimal combination and study their activity in different experimental conditions. However, additional studies should be conducted to ensure that these probiotic strains or their different compositions could be used in treatment or prevention of bacterial infections.

\section{Acknowledgements}

The research work was partially carried out under the project "Development of probiotics with antibacterial and immunomodulating properties on the basis of lacto- and bifidobacteria" (No 5979) that was financed by Ukraine and EU countries through the STCU. These studies are the part of L.P. Babenko's $\mathrm{PhD}$ thesis.

\section{List of literature}

1. Lodoen M.B., Lanier L.L. Natural killer cells as an initial defense against pathogens // Curr. Opin. Immunol. - 2006. - 18, № 4. - P. 391-398.

2. Role of natural killer cells in antibacterial immunity / S. Schmidt, E. Ullrich, K. Bochenne et al. // Expert. Rev. Hematol. 2016. - 9, № 12. - P. 1119-1127.

3. NK cell and DC interactions / M.A. Cooper, T.A. Fehniger, A. Fuchs et al. // Trends Immunol. - 2004. - 25, № 1. - P. 47-52.

4. Invasive surgery impairs the regulatory function of human CD56 bright natural killer cells in response to Staphylococcus aureus. Suppression of Interferon- $\gamma$ synthesis / R. Reinhardt, S. Pohlmann, H. Kleinertz et al. // PLoS One. - 2015. - 10, № 6. - P. e0130155.

5. Sha W.-H., Zeng X.-H., Min L. The correlation between NK cell and liver function in patients with primary hepatocellular carcinoma // Gut Liver. - 2014. - 8, № 3. - P. 298-305.

6. Decreased natural killer cell activity is associated with atherosclerosis in elderly humans / H. Bruunsgaard, A.N. Pedersen, M. Schroll et al. // Exp. Gerontol. - 2001. - 37, № 1. - P. 127-136.

7. Ojo-Amaize E.A., Conley E.J., Peter J.B. Decreased natural killer cell activity is associated with severity of chronic fatigue immune dysfunction syndrome // Clin. Infect. Dis. - 1994. - 18, № 1. - P. S157-S159.

8. Decreased risk of colorectal cancer with the high natural killer cell activity NKG2D genotype in Japanese / H. Furue, K. Matsuo, H. Kumimoto et al. // Carcinogenesis. - 2008. - 29, № 2. - P. 316-320.

9. NKC play a critical protective role in host defense against acute extracellular Staphylococcus aureus bacterial infection in the lung / C.L. Small, S. McCormick, N. Gill et al. // J. Immunol. - 2008 - 180, № 8. - P. 5558-5568.

10. Shirtliff M.E., Mader J.T. Acute septic arthritis // Clin. Microbiol. Rev. - 2002. - 15, № 4. - P. 527-544.

11. The emergence and evolution of methicillin-resistant Staphylococcus aureus // K. Hiramatsu, L. Cui, M. Kuroda et al. // Trends Microbiol. - 2001. - 9, № 10. - P. 486-493.

12. Exposure to particular matter increases susceptibility to respiratory Staphylococcus aureus infection in rats via reducing pulmonary natural killer cells / H. Zhao, W. Li, Y. Gao et al. // Toxicology. - 2014. - 325. - P. 180-188.

13. Protective role of NK1.1+ cells in experimental Staphylococcus aureus arthritis / N. Nilsson, T. Bremell, A. Tarkowski et al. // Clin. Exp. Immunol. - 1999. - 117, № 1. - P. 63-69.

14. Amdekar S., Singh V., Singh D.D. Probiotic therapy: immunomodulating approach toward urinary tract infection // Curr. Microbiol. - 2011. - 63, № 5. - P. 484-490.

15. Frei R., Akdis M., O'Mahony L. Prebiotics, probiotics, synbiotics, and the immune system: experimental data and clinical evidence // Curr. Opin. Gastroenterol. - 2015. - 31, № 2. - P. 153-158.

16. Distinct gut-derived lactic acid bacteria elicit divergent dendritic cell-mediated NK cell responses / L.N. Fink, L.H. Zeuthen, H.R. Christensen et al. // Int. Immunol. - 2007. - 19, № 12. - P. 1319-1327.

17. Role of natural killer and dendritic cell crosstalk in immunomodulation by commensal bacteria probiotics / V. Rizzello, I. Bonaccorsi, M.L. Dongarra et al. // J. Biomed. Biotechnol. - 2011. - 2011. - Article ID 473097. 
18. Consecutive oral administration of Bifidobacterium longum MM-2 improves the defense system against influenza virus infection by enhancing natural killer cell activity in a murine model / T. Kawahara, T. Takahashi, K. Oishi et al. // Microbiol. Immunol. - 2015. - 59, № 1. - P. 1-12.

19. Effect of Bifidobacterium on the immunity in BALB/c mice / J. Fan, Y. Hou, S. Zhou et al. // Wei Sheng Wu Xue Bao. 2015. - 55, № 4. - P. 484-491.

20. Antagonistic action of Lactobacilli and Bifidobacteria in relation to Staphylococcus aureus and their influence on the immune response in cases of intravaginal staphylococcosis in mice / L. Lazarenko, L. Babenko, L. Shynkarenko-Sichel et al. // Probiotics \& Antimicrob. Prot. - 2012. - 84, № 3. - P. 78-89.

21. Lactobacillus and Bifidobacterium influence the indices of immune response of the organism showed on experimental model / M.Ya. Spivak, V.S. Pidgorskyi, L.M. Lazarenko et al. // Microbiol Biotechnol. - 2009. - 1, № 5. - P. 39-46.

22. The role of beneficial bacteria wall elasticity in regulating innate immune response / V.V. Mokrozub, L.M. Lazarenko, L.M. Sichel et al. // EPMA J. - 2015. - 6, № 1. - P. 13.

23. Essential role of Toll-like receptors for dendritic cell and NK1.1(+) cell-dependent activation of type 1 immunity by Lactobacillus pentosus strain S-PT84 / S. Koizumi, D. Wakita, T. Sato et al. // Immunol. Lett. - 2008. - 120, № 1-2. - P. 14-19.

24. Effect of Lactobacillus brevis KB290 on the cell-mediated cytotoxic activity of mouse splenocytes: a DNA microarray analysis / Y. Fukui, E. Sasaki, N. Fuke et al. // Br. J. Nutr. - 2013. - 110, № 9. - P. 1617-1629.

25. A tolerant lactic acid bacteria, Lactobacillus paracasei, and its immunoregulatory function / X. Kou, Q. Chen, X. Ju et al. // Can. J. Microbiol. - 2014. - 60, № 11. - P. 729-736.

26. Differential cytokine regulatory effect of three Lactobacillus strains isolated from fermented foods / Y.D. Lee, Y.F. Hong, B. Jeon et al. // J. Microbiol. Biotechnol. - 2016. - 26, № 9. - P. 1517-1526.

27. Enhancement of natural killer cytotoxicity delayed murine carcinogenesis by a probiotic microorganism / A. Takagi, T. Matsuzaki, M. Sato et al. // Carcinogenesis. - 2001. - 22, № 4. - P. 599-605.

28. Immunomodulatory and antitumor effects in vivo by the cytoplasmic fraction of Lactobacillus casei and Bifidobacterium longum / J.W. Lee, J.G. Shin, E.H. Kim et al. // J. Vet. Sci. - 2004. - 5, № 1. - P. 41-48.

29. Lactobacillus casei ssp. casei induced Th1 cytokine profile and natural killer cells activity in invasive ductal carcinoma bearing mice / M.M. Soltan Dallal, M.H. Yazdi, M. Holakuyee et al. // Iran J. Allergy Asthma Immunol. - 2012. - 11, № 2. P. 183-189.

\section{References}

[1] M.B. Lodoen and L.L. Lanier, "Natural killer cells as an initial defense against pathogens", Curr. Opin. Immunol., vol. 18, no. 4, pp. 391-398, 2006. doi: 10.1016/j.coi.2006.05.002

[2] S. Schmidt et al., "Role of natural killer cells in antibacterial immunity", Expert. Rev. Hematol., vol. 9, no. 12, pp. 1119-1127, 2016. doi: $10.1080 / 17474086.2016 .1254546$

[3] M.A. Cooper et al., "NK cell and DC interactions", Trends Immunol., vol. 25, no. 1, pp. 47-52, 2004. doi: 10.1016/j.it.2003. 10.012

[4] R. Reinhardt et al., "Invasive surgery impairs the regulatory function of human CD56 bright natural killer cells in response to Staphylococcus aureus. Suppression of Interferon- $\gamma$ synthesis”, PLoS One, vol. 10, no. 6, e0130155, 2015. doi: 10.1371/journal. pone.0130155

[5] W.-H. Sha et al., "The correlation between NK cell and liver function in patients with primary hepatocellular carcinoma", Gut Liver, vol. 8, no. 3, pp. 298-305, 2014. doi: 10.5009/gnl.2014.8.3.298

[6] H. Bruunsgaard et al., "Decreased natural killer cell activity is associated with atherosclerosis in elderly humans", Exp. Gerontol., vol. 37, no. 1, pp. 127-136, 2001. doi: 10.1016/S0531-5565(01)00162-0

[7] E.A. Ojo-Amaize et al., "Decreased natural killer cell activity is associated with severity of chronic fatigue immune dysfunction syndrome”, Clin. Infect. Dis., vol. 18, no. 1, pp. S157-S159, 1994.

[8] H. Furue et al., "Decreased risk of colorectal cancer with the high natural killer cell activity NKG2D genotype in Japanese", Carcinogenesis, vol. 29, no. 2, pp. 316-320, 2008. doi: 10.1093/carcin/bgm260

[9] C.L. Small et al., "NKC play a critical protective role in host defense against acute extracellular Staphylococcus aureus bacterial infection in the lung", J. Immunol., vol. 180, no. 8, pp. 5558-5568, 2008. doi: 10.4049/jimmunol.180.8.5558

[10] M.E. Shirtliff and J.T. Mader, “Acute septic arthritis”, Clin. Microbiol. Rev., vol. 15, pp. 527-544, 2002. doi: 10.1128/CMR. 15.4.527-544.2002

[11] K. Hiramatsu et al., "The emergence and evolution of methicillin-resistant Staphylococcus aureus", Trends Microbiol., vol. 9, pp. 486-493, 2001.

[12] H. Zhao et al., "Exposure to particular matter increases susceptibility to respiratory Staphylococcus aureus infection in rats via reducing pulmonary natural killer cells", Toxicology, vol. 5, no. 325, pp. 180-188, 2014. doi: 10.1016/j.tox.2014.09.006 
[13] N. Nilsson et al., "Protective role of NK1.1+ cells in experimental Staphylococcus aureus arthritis", Clin. Exp. Immunol., vol. 117, no. 1, pp. 63-69, 1999. doi: 10.1046/j.1365-2249.1999.00922.x

[14] S. Amdekar et al., "Probiotic therapy: immunomodulating approach toward urinary tract infection", Curr. Microbiol., vol. 63, no. 5, pp. 484-490, 2011. doi: 10.1007/s00284-011-0006-2

[15] R. Frei et al., "Prebiotics, probiotics, synbiotics, and the immune system: experimental data and clinical evidence, Curr. Opin. Gastroenterol., vol. 31, no. 2, pp. 153-158, 2015. doi: 10.1097/MOG.0000000000000151

[16] L.N. Fink et al., "Distinct gut-derived lactic acid bacteria elicit divergent dendritic cell-mediated NK cell responses", Int. Immunol., vol. 19, no. 12, pp. 1319-1327, 2007. doi: 10.1093/intimm/dxm103

[17] V. Rizzello et al., "Role of natural killer and dendritic cell crosstalk in immunomodulation by commensal bacteria probiotics", J. Biomed. Biotechnol., vol. 2011, ID 473097, 2011. doi: 10.1155/2011/473097

[18] T. Kawahara et al., "Consecutive oral administration of Bifidobacterium longum MM-2 improves the defense system against influenza virus infection by enhancing natural killer cell activity in a murine model”, Microbiol. Immunol., vol. 59, no. 1, pp. 1-12, 2015. doi: 10.1111/1348-0421.12210

[19] J. Fan et al., "Effect of Bifidobacterium on the immunity in BALB/c mice", Wei Sheng Wu Xue Bao, vol. 55, no. 4, pp. 484-491, 2015.

[20] L. Lazarenko et al., "Antagonistic action of Lactobacilli and Bifidobacteria in relation to Staphylococcus aureus and their influence on the immune response in cases of intravaginal staphylococcosis in mice”, Probiotics Antimicrob Proteins., vol. 84, no. 3, pp. 78-89, 2012. doi: 10.1007/s12602-012-9093-Z

[21] M.Ya. Spivak et al., "Lactobacillus and Bifidobacterium influence the indices of immune response of the organism showed on experimental model”, Microbiol. Biotechnol., vol. 1, no. 5, pp. 39-46, 2009.

[22] V.V. Mokrozub et al., "The role of beneficial bacteria wall elasticity in regulating innate immune response", EPMA J., vol. 6, no. 1 , p. 13, 2015. doi: $10.1186 / \mathrm{s} 13167-015-0035-1$

[23] S. Koizumi et al., "Essential role of Toll-like receptors for dendritic cell and NK1.1(+) cell-dependent activation of type 1 immunity by Lactobacillus pentosus strain S-PT84”, Immunol. Lett., vol. 120, no. 1-2, pp. 14-19, 2008. doi: 10.1016/j.imlet. 2008.06.003

[24] Y. Fukui et al., "Effect of Lactobacillus brevis KB290 on the cell-mediated cytotoxic activity of mouse splenocytes: a DNA microarray analysis", Br. J. Nutr., vol. 110, no. 9, pp. 1617-1629, 2013. doi: 10.1017/S0007114513000767

[25] X. Kou et al., "A tolerant lactic acid bacteria, Lactobacillus paracasei, and its immunoregulatory function", Can. J. Microbiol., vol. 60, no. 11, pp. 729-736, 2014. doi: 10.1139/cjm-2014-0383

[26] Y.D. Lee et al., "Differential cytokine regulatory effect of three Lactobacillus strains isolated from fermented foods", J. Microbiol. Biotechnol., vol. 26, no. 9, pp. 1517-1526, 2016. doi: 10.4014/jmb.1601.01044

[27] A. Takagi et al., "Enhancement of natural killer cytotoxicity delayed murine carcinogenesis by a probiotic microorganism", Carcinogenesis, vol. 22, no. 4, pp. 599-605, 2001. doi: 10.1093/carcin/22.4.599

[28] J.W. Lee et al., "Immunomodulatory and antitumor effects in vivo by the cytoplasmic fraction of Lactobacillus casei and Bifidobacterium longum”, J. Vet. Sci., vol. 5, no. 1, pp. 41-48, 2004.

[29] M.M. Soltan Dallal et al., "Lactobacillus casei ssp. casei induced Th1 cytokine profile and natural killer cells activity in invasive ductal carcinoma bearing mice”, Iran J. Allergy Asthma Immunol., vol. 11, no. 2, pp. 183-189, 2012. doi: 011.02/ijaai.183189

\section{Л.М. Лазаренко, Л.П. Бабенко, В.В. Мокрозуб, М.А. Воронкевич, Д.В. Лосєва, Л.М. Сішел, М.Я. Співак}

\section{ВПЛИВ ЛАКТОБАЦИЛ І БІФІДОБАКТЕРІЙ НА КІЛЬКІСТЬ ПРИРОДНИХ КІЛЕРНИХ КЛІТИН У НОРМІ ТА ЗА ІНТРАВАГІ- НАЛЬНОЇ СТАФІЛОКОКОВОЇ ІНФЕКЦІЇ У МИШЕЙ}

Проблематика. Розробка нових імунобіотиків на основі непатогенних коменсальних пробіотичних бактерій, таких як лактобацили і біфідобактерії з антибактеріальною та імуномодулювальною дією, є важливим напрямом сучасної біотехнології.

Мета дослідження. Метою роботи є визначення впливу Lactobacillus acidophilus IMB B-7279, L. casei IMB B-7280, L. delbrueckii subsp. bulgaricus IMB B-7281, Bifidobacterium animalis VKL та B. animalis VKB (окремо) або їх різних композицій на кількість природних кілерних клітин (ПКК) у селезінці мишей лінії BALB/c у нормі та за експериментальної інтравагінальної стафілококової інфекції.

Методика реалізації. Кількість ПКК у селезінці визначали з використанням моноклональних фрікоеритрин-кон'югованих антитіл проти антигенів ПКК (MACS, Miltenyi Biotec, Німеччина). Підрахунок ПКК, а також аналіз результатів проводили на цитофрлюориметрі FACStar Plus.

Результати дослідження. Показано, що під впливом L. acidophilus IMB B-7279, L. casei IMB B-7280, B. animalis VKL та B. animalis VKB (окремо) кількість ПКК у селезінці інтактних мишей не змінювалась. Проте використання для колонізації піхви L. acidophilus IMB B-7279, L. casei IMB B-7280, L. delbrueckii subsp. bulgaricus IMB B-7281, B. animalis VKL ta B. animalis VKB (окремо) або їх різних композицій за інтравагінальної стафрілококової інфекції було пов'язане зі збільшенням кількості ПКК у селезінці мишей у різні періоди спостереження. В селезінці інфрікованих стафрілококом мишей кількість ПКК повністю нормалізувалась після використання для лікування певних пробіотичних композицій. Пробіотичні бактерії (окремо) нормалізували кількість ПКК у селезінці інфрікованих стафілококом мишей лише частково. 
Висновки. L. acidophilus IMB B-7279, L. casei IMB B-7280, L. delbrueckii subsp. bulgaricus IMB B-7281 та B. animalis VKL (окремо) або їх різні композиції $є$ перспективними для створення високоефективних імунобіотиків, які здатні посилити вроджений імунітет при інфекційних хворобах. миші.

Ключові слова: лактобацили; біфідобактерії; природні кілерні клітини; селезінка; інтравагінальна стафілококова інфекція;

Л.Н. Лазаренко, Л.П. Бабенко, В.В. Мокрозуб, М.А. Воронкевич, Д.В. Лосева, Л.Н. Сишел, Н.Я. Спивак

ВЛИЯНИЕ ЛАКТОБАЦИЛЛ И БИФИДОБАКТЕРИЙ НА КОЛИЧЕСТВО ЕСТЕСТВЕННЫХ КИЛЛЕРНЫХ КЛЕТОК В НОРМЕ И ПРИ ИНТРАВАГИНАЛЬНОЙ СТАФИЛОКОККОВОЙ ИНФЕКЦИИ У МЫШЕЙ

Проблематика. Разработка новых иммунобиотиков на основе непатогенных коменсальних пробиотических бактерий, таких как лактобациллы и бифидобактерии с антибактериальным и иммуномодулирующим действием, является важным направлением современной биотехнологии.

Цель исследования. Целью работы является определение влияния Lactobacillus acidophilus ИМB B-7279, L. casei ИМВ B-7280, L. delbrueckii subsp. bulgaricus ИMB B-7281, Bifidobacterium animalis VKL и B. animalis VKВ (индивидуально) или их различных композиций на количество естественных киллерных клеток (ЕКК) в селезенке мышей линии BALB/c в норме и при экспериментальной интравагинальной стафилококковой инфекции.

Методика реализации. Количество ЕКК в селезенке определяли с использованием моноклональных фикоэритрин-конъюгированных антител против антигенов ЕКК (MACS, Miltenyi Biotec, Германия). Подсчет ЕКК, а также анализ результатов проводили на цитофлюориметре FACStar Plus.

Результаты исследования. Показано, что под влиянием L. acidophilus ИMB B-7279, L. casei ИMB B-7280, B. animalis VKL и B. animalis VKB (индивидуально) количество ЕКК в селезенке интактных мышей не изменялось. Однако использование для колонизации влагалища L. acidophilus ИМВ B-7279, L. casei ИMB B-7280, L. delbrueckii subsp. bulgaricus ИMB B-7281, B. animalis VKL и B. animalis VKB (индивидуально) или их различных композиций в случае интравагинальной стафилококковой инфекции было связано с увеличением количества ЕКК в селезенке мышей в различные периоды наблюдения. В селезенке инфицированных стафилококком мышей количество ЕКК полностью нормализовалось после использования для лечения пробиотических композиций. Пробиотические бактерии (индивидуально) нормализовали количество ЕКК в селезенке инфицированных стафилококком мышей лишь частично.

Выводы. L. acidophilus ИМВ В-7279, L. casei ИМВ В-7280, L. delbrueckii subsp. bulgaricus ИМВ В-7281 и В. animalis VKL (индивидуально) и их различные композиции являются перспективными для создания высокоэффективных иммунобиотиков, способных усилить врожденный иммунитет при инфекционных болезнях.

Ключевые слова: лактобациллы; бифидобактерии; естественные киллерные клетки; селезенка; интравагинальная стафилококковая инфекция; мыши.

Рекомендована Радою

факультету біотехнології і біотехніки

КПІ ім. Ігоря Сікорського
Надійшла до редакції

07 березня 2017 року 